\title{
Reproductive role of prolactin
}

\author{
Anne Bachelot ${ }^{1,2,3}$ and Nadine Binart ${ }^{1,2}$ \\ ${ }^{1}$ Inserm, Unit 809, Paris, France, ${ }^{2}$ Faculty of Medicine René Descartes, University Paris-Descartes, Paris 5-Necker site, \\ Paris, France and ${ }^{3}$ AP HP, Department of Endocrinology and Reproductive Medicine, GH Pitie Salpetriere, Paris, \\ France
}

Correspondence should be addressed to N Binart, Inserm, Unit 809, Paris, France; Email: binart@necker.fr

\begin{abstract}
The biological actions of prolactin (PRL), a polypeptide hormone, are mostly related to lactation and reproduction. These actions have been clarified by studies of PRL and PRL-deficient receptor mice, which have a clear phenotype of reproductive failure at multiple sites. This review aims to summarize current knowledge about PRL and its receptor, role in reproductive axis and presents information of hyperprolactinemia in reproductive medicine. Our understanding of the physiology and transduction pathway of PRL has largely increased in the past 20 years with the cloning of PRL and its receptor gene.

Reproduction (2007) 133 361-369
\end{abstract}

\section{Prolactin}

Prolactin (PRL) is mainly synthesized and secreted by the lactotrop cells of the pituitary (Freeman et al. 2000), but also by extrapituitary sites such as mammary gland, placenta, uterus and T lymphocytes (Ben-Jonathan et al. 1996). Its amino acid sequence is similar to that of growth hormone $(\mathrm{GH})$ and placenta lactogen $(\mathrm{PL})$ sharing genomic, structural and biological features and belonging to the same PRL/GH/PL protein family. It is now considered that PRL is a cytokine, based on both molecular and functional evidence (Horseman \& Yu-Lee 1994).

The gene encoding PRL is unique, in humans it is located on chromosome 6 (Horseman \& Yu-Lee 1994), and was initially described as containing five exons and four introns for an overall length of $10 \mathrm{~kb}$, since then, an additional exon 1a has been described. After removal of the signal peptide (28 residues), the mature form of the protein contains 199 residues ( $23 \mathrm{kDa})$. Several variants of PRL resulting from posttranslational modifications have been identified (Sinha 1995). Moreover, it has been described some proteolytic cleavage of PRL via cathepsin $\mathrm{D}$, resulting into 16 and $6 \mathrm{kDa}$ fragments (Baldocchi et al. 1993) or via kallikerin giving rise to a $22 \mathrm{kDa}$ fragment. Very recently, it has been shown that cathepsin D, secreted from various tissues, is able to process PRL into anti-angiogenic $16 \mathrm{kDa}$ PRL outside the cell. The data support the concept that secreted lysosomal enzymes could be involved in the maintenance of angiogenesis dormancy via the generation of active anti-angiogenic peptides in nonpathological contexts (Piwnica et al. 2006). Phosphorylation of PRL constitutes $5-30 \%$ of the PRL released by the pituitary, but the function of PRL phosphorylation is widely debated. In fact, it has been shown that phosphorylated PRL can have agonistic and antagonistic properties (Bernichtein et al. 2001, Wu et al. 2003). The function of some other modifications of PRL (by glycosylation, deamination, sulfonation and polymerization; Sinha 1995) are not well studied.

\section{Prolactin receptor and signalization}

$P R L$, as well as PL and primate $\mathrm{GH}$, binds the same PRL receptor (PRLR). Multiple isoforms of membrane-bound PRLR resulting from alternative splicing of the primary transcript have been identified in several species (Bole-Feysot et al. 1998). These different PRLR isoforms (short and long) differ in the length and composition of their cytoplasmic tail.

The understanding of how PRL transmits diverse signals to target cells is facilitated by the elucidation of the JAK/Stat pathway as the prototype signaling pathway used by all cytokine receptors (Fig. 1). PRL is believed to activate sequentially the receptor by dimerizing two identical receptor subunits, leading to activation of Jak2 kinase associated with the cytoplasmic domain. Recently, it has been reported for the growth hormone receptor (GHR) that dimerization alone is insufficient to activate full-length receptor; then it has been proposed for the GHR, an activation mechanism involving a 


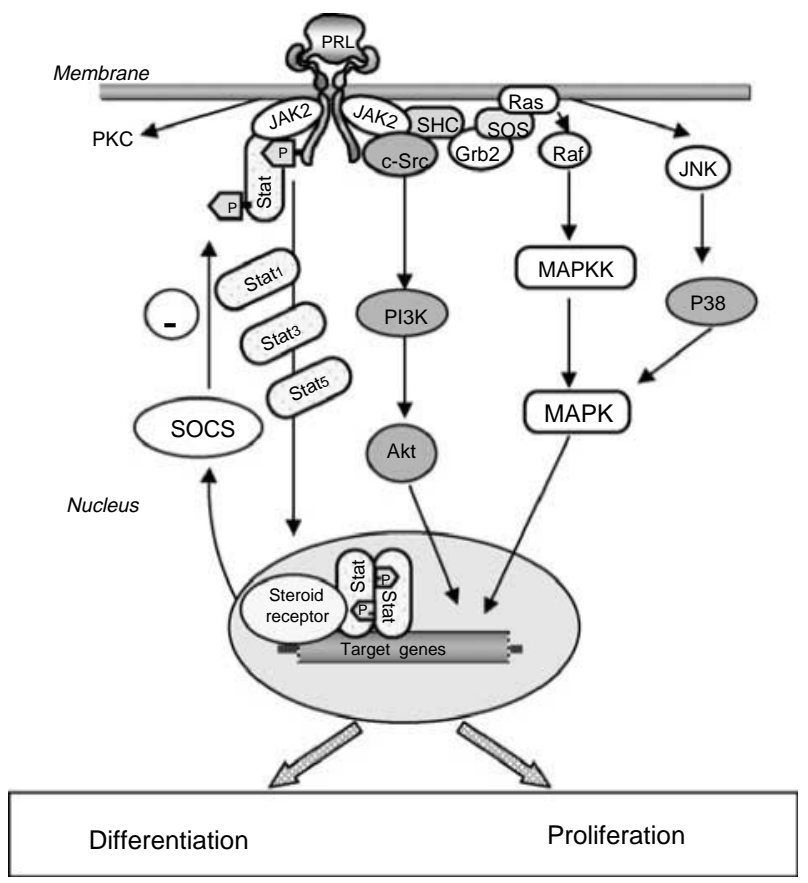

Figure 1 Signal transduction pathways of PRL. PRL-induced receptor dimerization induces the association of the Jak2 kinase, resulting in the activation of Jak2, PRLR phosphorylation, and the association and phosphorylation of Stat1, 3 or 5 proteins. This triggers Stat dimerization and nuclear translocation and events necessary for PRL-triggered differentiation. Signaling through the SHC/GRB2/Ras/Raf/MEK/MAPK pathway also directly stimulates proliferation and modulates Stat activity. Activation of the kinase Akt is directly tied to the PRL-induced activation of PI3K. Members of the CIS family, also known as SOCS, also modulate cytokine signaling. These proteins are rapidly induced after prolactin stimulation with distinct time courses depending on the CIS/SOCS family member. They interact with the receptors and/or Jak2, and either inhibit signaling or relieve suppression.

relative rotation of subunits within a dimeric receptor as a result of asymmetric placement of the receptor-binding sites on the ligand (Brown et al. 2005). Very recent studies have suggested that long and intermediate PRLR receptor isoforms could also be dimerized irrespective of the ligand binding (Tan et al. 2005, Gadd \& Clevenger 2006, Qazi et al. 2006). Hormonal stimulation of PRLR leads to tyrosine phosphorylation of several cellular proteins, including the receptor itself. The PRLR-Jak2 interaction involves the membrane-proximal region of the PRLR cytoplasmic domain, in agreement with the ability of the short PRLR isoform to associate with the kinase (Binart et al. 2003a). It is assumed that activation of Janus kinases occurs by trans-phosphorylation of tyrosines upon ligand-induced oligomerization of cytokine receptors, which brings two JAK molecules close to each other (Ihle \& Kerr 1995). Jak2 Phosphorylates tyrosine residues on different target proteins, the best identified of which is the receptor itself and a family of transcription factors termed signal transducers and activators of transcription (Stats). These factors are signaling the molecules containing consensus domains involved in protein-protein interactions, such as $\mathrm{SH} 2$ or PTB domains recruited by phosphorylated tyrosines of the PRLR-Jak2 complex. Stat proteins exist within the cytoplasm in a latent or inactive state; they are recruited by cytokine receptor complexes through an interaction involving a phosphotyrosine (on the cytokine receptor and/or the associated JAK) and the $\mathrm{SH} 2$ of the Stat protein. Three members of the Stat family have been thus far identified as transducer molecules of the PRLR: Stat1, Stat3 and, mainly, Stat5 (both a and b isoforms). Stat5 was originally identified as mammary gland factor (MGF; Wakao et al. 1995) and is the major Stat activated by the PRLR. It is preferentially recruited by the C-terminal tyrosine of the receptor. Both Stat 1 and Stat 3 also have been reported to be activated by the PRLR. After activation, Stats dimerize and migrate to the nucleus, where they specifically interact with DNA sequences (a palindromic consensus sequence TTC xxx GAA (Ihle 1996)) within the promoters of target genes. Then they bind to their cognate DNA-binding sequence resulting in promoter transactivation under appropriate conditions. Once bound, Stats engage several elements of the transcriptional machinery, stimulating gene expression. Very recently, a novel mechanism of PRL signaling has been identified in mammary epithelial cells demonstrating that nuclear Jak2 regulates the amount of active nuclear transcription factor through tyrosine phosphorylation and proteasomal degradation (Nilsson et al. 2006).

Although the Jak2-Stat cascade is the major signaling pathway used by the PRL receptor, other transducing pathways are also involved in signal transduction by this receptor. Signaling through MAP kinases (MAPK) 
involves the Shc/Grb2/SOS/Ras/Raf/MAPK cascade. Activation of the MAPK pathway has been reported in different cellular systems under PRL stimulation (see (Bole-Feysot et al. 1998)). Activation of the nucleotide exchange protein Vav has also been reported (Clevenger et al. 1995). It has also been shown that PRL induces a rapid tyrosine phosphorylation of the insulin receptor substrate 1 (IRS-1) and of the $85 \mathrm{kDa}$ subunit of the phosphatidylinositol (PI)-3' kinase (Berlanga et al. 1997). Both PI-3' kinase and IRS-1 appear to associate with the PRLR in a PRL-dependent manner. The existence of two PRL-dependent signaling cascades has been initiated by the c-Src-mediated activation of Fak/Erk1/2 and PI3K pathways that control the expression of c-Myc and cyclin D1 and the proliferation. In agreement with the fact that most transducer molecules are activated by tyrosine phosphorylation (JAKs, Stats, Src, etc.), involvement of tyrosine phosphatases to modulate or down-regulate the signaling cascades is expected. It has been reported that the phosphatase SHP-2 is activated by Jak2 and acts as a positive regulator of PRLR-dependent induction of $\beta$-casein gene transcription (Ali et al. 1996). Moreover, a group of molecules whose expression is induced by PRL feedbacks to inhibit further signaling from the PRLR. These include suppressors of cytokine signaling (SOCS), which bind to and inhibit JAK; and PIAS (protein inactivator of activated Stat), which bind to and inhibit Stats. These data would indicate that JAK inhibition by SOCS proteins occurs either as a binary complex between JAK-SOCS or as a ternary complex constituted of JAK-SOCS-receptor.

\section{PRL and reproduction}

PRL exerts multiple effects, regulating both differentiation and proliferation in diverse tissues (Bole-Feysot et al. 1998). A large body of literature attests that lactogenic hormones play a role in reproductive function. A number of PRL key functions have been clarified from studies of transgenic and knockout model mice. Accordingly, $\mathrm{PRL}-/-$ female mice are completely infertile. After mating with males of established fertility, no litters were produced following several matings. Each female mated repeatedly at irregular intervals, without entering a state of pseudopregnancy. Estrous cycles were irregular, and individual females failed to establish any consistent pattern of cycling. All these observations led to the conclusion that PRL is essential to female reproduction (Horseman et al. 1997).

\section{Function of the ovarian corpus luteum}

PRL plays a critical role in corpus luteum maintenance and progesterone production in rodents (Risk \& Gibori 2001), but not in other mammals; while synthesis of PRL by the decidua is unique to humans. PRLR $-/-$ female mice showed an absence of pseudopregnancy and an arrest of egg development immediately after fertilization, with only a few reaching the stage of blastocysts (Ormandy et al. 1997). The outcome is a complete sterility. Uterine preparation for embryo implantation is dependent upon continued estrogen and progesterone secretion by the corpus luteum, which is supported by a functional pituitary during the first half of pregnancy in rodents. Thus, whereas PRLR $-/-$ females cannot implant blastocysts, the defect of the preimplantation egg development can be rescued by exogenous progesterone, indicating that one of the actions of PRL is to stimulate ovarian production of progesterone. However, although implantation occurs, full term pregnancy is not achieved (Binart et al. 2000), most probably because of the absence of decidual PRLR. Indeed, the rodent decidua was shown to express both PRL (Prigent-Tessier et al. 1999) and its receptor (Gu et al. 1996). The role of decidual PRL appears to involve the local stimulation of the estradiol receptor and the inhibition of decidual IL- 6 and $20 \alpha-$ HSD (hydroxysteroid dehydrogenase), both of which are detrimental to fetal life. Cells of PRLR $-/-$ corpus luteum failed to organize appropriately and underwent dramatic apoptosis, clearly demonstrating the anti-apoptotic role of PRL (Grosdemouge et al. 2003; Fig. 2). Proliferation of endothelial cells is required for the neovascularization during luteal development, which results in the corpus luteum's extensive capillary network. It is known, in rats, that PRL secretion induced by mating leads to the increased endothelial cell proliferation in the corpus luteum of pregnancy. Its survival beyond diestrus depends on PRL stimulation and it is associated with an increase in luteal size and vascularization. In the PRLR - / - corpus luteum, such a vascularization failed to develop and thus the presence of the PRLR appears to be crucial for the induction of vascular factors. Indeed, low levels of progesterone in PRLR $-/-$ are independent of the proliferative state and the accumulation of corpora, undergoing regression expressing high levels of $20 \alpha-H S D$, would further contribute to a decrease in the levels of progesterone. The ovulation rate is not different between PRLR $+/+$ and PRLR $-/-$ mice, and the corpus luteum is formed but an elevated level of apoptosis and extensive inhibition of angiogenesis occur during the luteal transition in the absence of PRL signaling. These modifications lead to the decrease of luteinizing hormone $(\mathrm{LH})$ receptor expression and consequently to a loss of the enzymatic cascades necessary to produce adequate levels of progesterone, which are required for the maintenance of pregnancy. In the reproductive system, PRL induces transcription of the estrogen receptor (Frasor \& Gibori 2003) and the enzyme $3 \beta$-hydroxysteroid dehydrogenase involved in progesterone synthesis (Feltus et al. 1999).

The mechanism controlling luteal function, principally in ruminants, has been largely reviewed 

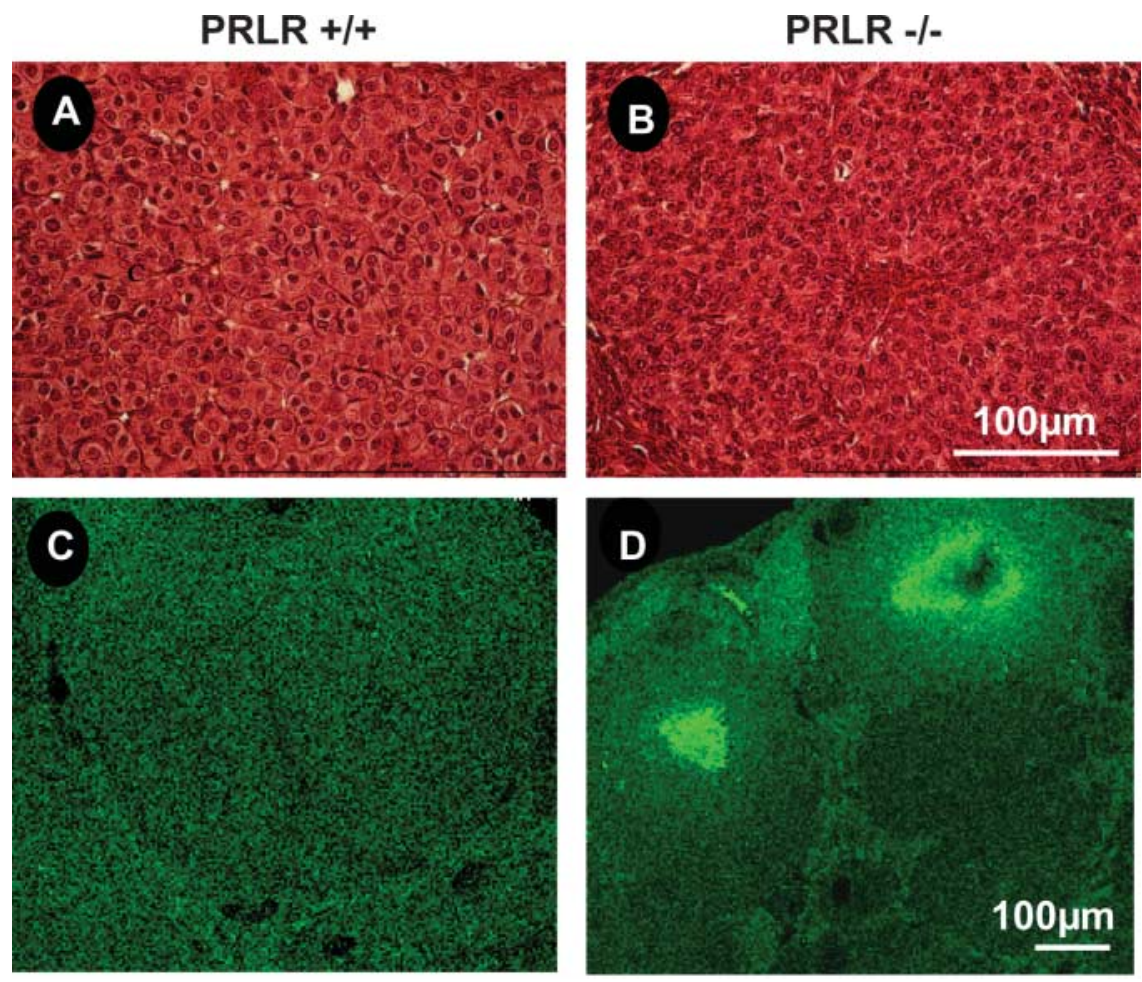

Figure 2 Histological analysis of ovary from wild-type and PRLR -/ - mice. Representative view of corpus luteum sections of ovaries from PRLR $+/+$ (A) and PRLR - / - (B) from 8-week-old female mice. Detection of apoptosis in control $+/+(\mathrm{C})$ and PRLR $-/-$ (D) corpora lutea by the Tunel method at day 2.5 after fertilization. Apoptotic nuclei are labeled green by Tunel with fluorescein detection. Analysis of sections by confocal microscopy exhibits fluorescence only in PRLR - / - ovaries, where several apoptotic nuclei are present in PRLR $-/-$. Scale bar is $100 \mu \mathrm{m}$.
(Niswender et al. 2000, Webb et al. 2002), other aspects of luteal function such as angiogenesis and overall role of the luteal microvasculature have also been revisited (Reynolds \& Redmer 1999, Davis et al. 2003, Tamanini \& De Ambrogi 2004).

\section{Development of the mammary gland}

Continued proliferation and branching lead to the formation of a small ductal tree at birth, whereas the fat pad forms the stroma of the adult mammary gland. Mammary glands develop from the surface epithelium and underlying mesenchyme; however, the molecular controls of embryonic mammary development are largely unknown. The essential hormonal factors, regulating the later phases of mammary gland development in mice, have been established to be estrogen, glucocorticoids and GH during puberty, and estrogen, progesterone and placental lactogen and/or PRL during pregnancy (Nandi 1958, Neville \& Daniel 1987). Functional development of mammary epithelium during pregnancy depends mostly on PRL signaling. Proliferation and differentiation of secretory mammary epithelium is dependent on the presence of PRL receptor as well as its downstream Jak2-Stat5 pathway. However, the underlying molecular and cellular events are not completely understood. The specific contributions of the PRL receptor and the transcriptional factors Stat5a and $5 b$, in the formation and differentiation of mammary alveolar epithelium, have been explored (Miyoshi et al. 2001). By transplantation of PRLR- and Stat5-null mammary epithelia into wild-type hosts, the pregnancy-mediated development was investigated at both histological and molecular level. Stat5-null mammary epithelium developed ducts but failed to form alveoli, and no milk protein gene expression was observed. In contrast, PRLR-null epithelium formed alveoli-like structures with small open lumina. Electron microscopy revealed a perturbation of cell-cell contacts in PRLR- and Stat5-null epithelia. Expression of NKCC1, an $\mathrm{Na}-\mathrm{K}-\mathrm{Cl}$ cotransporter characteristic for ductal epithelia, and a protein associated with tight junction (ZO-1), were maintained in the alveoli-like structures of PRLR- and Stat5-null epithelia. In contrast, the $\mathrm{Na}-\mathrm{Pi}$ cotransporter Npt2b, and the gap junction component connexin 32, usually expressed in secretory epithelia, was undetectable in PRLR- and Stat5-null mice. Collectively, these data demonstrate that signaling via the PRLR and Stat5 is critical for the proliferation and differentiation of mammary alveoli during pregnancy.

Mammary development in PRL (Horseman et al. 1997) and PRL receptor (Ormandy et al. 1997) null mice is essentially blocked at the stage of extended ductal outgrowths, which is reasonable since most of the development of the mammary gland in mice occurs during pregnancy and since these female are sterile. Transplantation experiments of PRLR - / - epithelium to the mammary fat pad of an immunocompromised animal allows examination of PRLR - / - mammary gland development in a normal endocrine environment, allowing development during pregnancy to be assessed. The transplanted PRLR-/- epithelium develops side 
branches in virgin animals, however during pregnancy a complete failure of lobulo-alveolar development is observed and only alveolar buds are produced (Brisken et al. 1999). In agreement, the mammary glands of PRLR $-/-$ animals that could maintain pregnancy, following progesterone treatment, also experience failure of lobulo-alveolar development (Binart et al. 2000; Fig. 3). PRL receptors are present in the stroma (Camarillo et al. 2001, Hovey et al. 2001), but play no direct role in mammary gland development. In fact in mammary glands, constituted of PRLR - / stroma and PRLR+/+ epithelium (Ormandy et al. 2003), a normal development occurs but it is not known whether these receptors are essential for the lactation function.

The impaired mammary development and alveolar differentiation seen during pregnancy in the hemizygous PRLR mice suggests that the level of signaling flux initiated by PRL can modulate mammary gland development. It corresponds to a reduction in Stat5 phosphorylation levels, and markedly reduced expression of milk protein genes. Development of the glands in these mice is arrested at around mid pregnancy. While PRL activates Stat5 only in the mammary epithelium, GH activates Stat5 preferentially in the stroma. Ductal development in GHR-null mice is impaired; these observations support
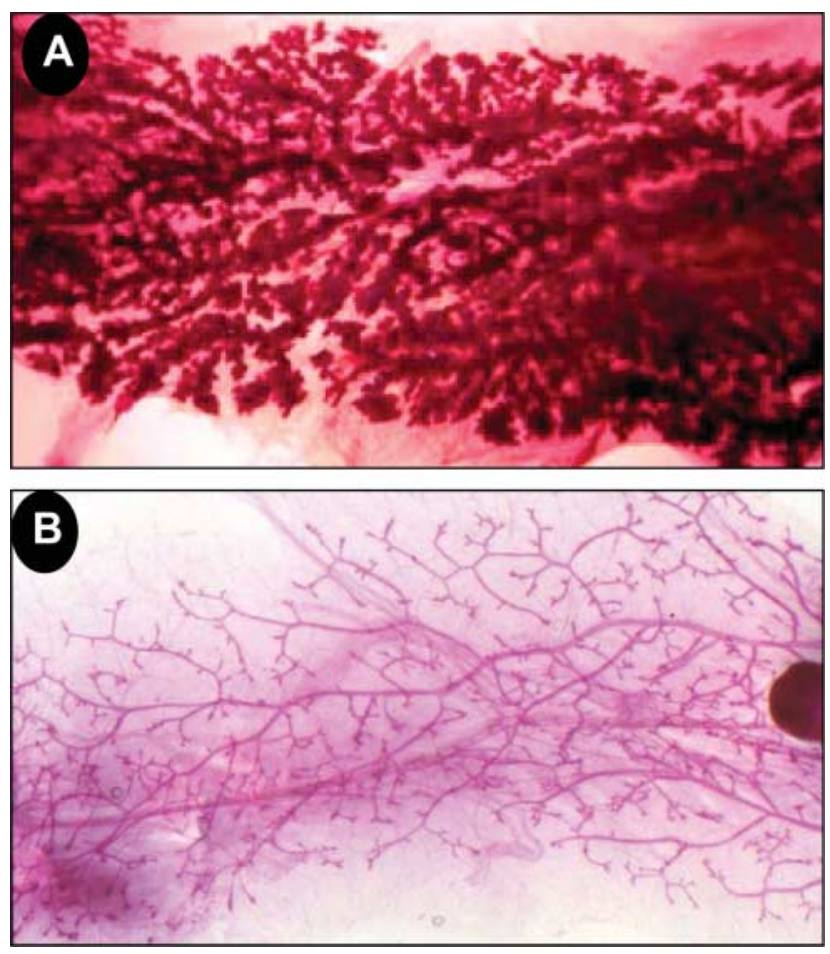

Figure 3 Histological analysis of mammary gland from wild-type and PRLR -/- mice. Representative ductal branching and lobulo-alveolar development of pregnant wild type, and knockout mice. The fourth inguinal mammary gland was analyzed using whole-mount histology at day 18.5 of pregnancy in wild-type (A) and in progesterone treated PRLR $-/-$ mouse (B). the notion that $\mathrm{GH}$ signals through the stromal compartment. Taken overall, it has been demonstrated that $\mathrm{GH}$ and PRL activate Stat5 in separate compartments, which in turn reflects their specific role in ductal and alveolar development and differentiation (Gallego et al. 2001).

Mice in which either one or both Stat5a and Stat5b genes were inactivated have revealed unique and redundant roles of the two Stat5 isoforms. Stat5a deficiency results in the loss of PRL-dependent mammary gland development (Liu et al. 1997), in contrast, inactivation of Stat $5 b$ does not adversely affect mammary development and function but leads to severe growth retardation (Udy et al. 1997).

In mice, alternative splicing of the $P R L R$ gene results in four different forms, each having a different cytoplasmic length. The function of the long form is now clearly established, however the functions of the three short forms of the receptor are not well characterized. Transgenic mice expressing the rat short form (F3-SPRLR) of the receptor in the mammary glands results in reduced alveolar development, Stat5 phosphorylation and milk protein expression but no change in proliferation (Saunier et al. 2003), suggesting that this form may act as a dominant negative to control the rate of differentiation occurring in the mammary gland. Transgenic expression of another short form (S1) in PRLR +/ - mice, normally unable to lactate following their first pregnancy, restores mammary gland development at the level of proliferation and differentiation, indicating that this form acts in a similar way to the long form (Binart et al. 2003a). The function of the short S2 form has not been evaluated to date.

A number of transcript profiling studies have recently been undertaken using these mice models; they should reveal molecular candidates regulated by $P R L$ at the transcriptional level. These candidates include cytokeratins, cell adhesion molecules, transcription factors and a number of growth factors already shown important for mammary development. Among them, IGF2 and RankL have been demonstrated crucial. These data highlight a new role of IGF2 as a mediator of PRL-induced morphogenesis in breast (Brisken et al. 2002, Hovey et al. 2003) and indicate that IGF2 acts downstream of PRL and upstream of cyclin D1.

\section{Maternal behavior}

Maternal behavior in PRL-/- mice is normal (Horseman et al. 1997), however pup-induced maternal behavior in both virgin and pregnant PRLR $-/-$ or PRLR + / - mice is significantly reduced, independent of other behavioral activities and olfactory function, implicating the receptor as an important regulator of maternal behavior (Lucas et al. 1998). Moreover, the decrease in maternal behavior is associated with failure of lactation in PRLR+/- females (Lucas et al. 1998). 
In addition, the molecular mimic of phosphorylated PRL, $\mathrm{S} 179 \mathrm{D}$, is able to delay the onset of normal maternal behavior in rats (Bridges et al. 2001). During pregnancy and lactation, it has been recently reported that new neurons produced in the forebrain migrate to the olfactory bulb where they likely participate in processing olfactory cues received by the new mother as they adapt to the needs and challenges of raising pup (Shingo et al. 2003). These new neurons established functional connections on day 7 of pregnancy as well as day 7 of lactation, it was also apparent in pseudopregnant females and that the response could be generated solely by changes associated with mating. The authors demonstrated that neurogenesis was inducible by either systemic or central administration of PRL. This constitutes the first demonstration that a hormone can stimulate the genesis, migration and differentiation of neurons in the adult mammalian brain and the first evidence that rates of neurogenesis can be influenced by alterations in the endocrine state.

\section{PRL and male function}

A preliminary analysis of male fertility described a proportion of $20 \%$ of PRLR-/- infertile males, however this was not due to a defect in mating behavior (Grosdemouge et al. 2003). Two subsequent studies using separate PRLR $-/-$ mouse lines that originated from this initial study population, but which have since diverged, have re-examined this phenotype. One study found no effect on fertility (Binart et al. 2003b), whereas the other showed that a proportion of $10 \%$ are infertile and those that are fertile only have a $40 \%$ chance of producing a successful first pregnancy (Robertson et al. 2003). These contrasting data may be due to the effect of PRL on male reproduction being modified by divergence in the genetic background. Moreover, PRL $-/-$ males are fertile, although PRL does play a role in reproductive neuroendocrine function by control of $\mathrm{LH}$ release (Steger et al. 1998). Then, it appears that PRL plays a modest role on male fertility contrary to that on female fertility.

PRL and its receptor are expressed in human and rat prostate epithelial cells, where their level is increased by androgen treatment (Nevalainen et al. 1997a), it has been also viewed as an autocrine/paracrine growth factor (Nevalainen et al. 1997b) or a survival factor (Ahonen et al. 1999) for the prostate epithelial cells in vitro. Prostate weight is slightly increased in young PRLR $-/$ - animals and some changes in epithelial and stromal content of the dorsal lobe occur probably regulated by cooperation between PRL and androgens (Robertson et al. 2003). PRL has a subtle role in the prostate, whereas hyperprolactinemia has a direct effect on hyperplasia of the prostate. This is in accordance with the role of PRL on cellular proliferation.

\section{Prolactin and reproductive medicine}

Against a background of substantial knowledge of the biology of PRL, a large amount of clinical experience has been gathered about hyperprolactinemia in humans and its best treatment. Circulating serum PRL in normal individuals is thought to reflect almost entirely pituitary PRL secretion: other extra pituitary sources probably contribute significant amounts mainly to the local tissue environment. In contrast to what is observed for other pituitary hormones, no mutation of the $P R L$ gene or of the $P R L R$ gene has been described yet, so that there is no clinical model to clearly evaluate the consequences of the absence of PRL actions in humans.

Clinically, high PRL levels have been associated with certain autoimmune diseases (Walker et al. 1998). There are also several intersections between PRL, psychological stress and chronic hyperprolactinemia reviewed in (Sobrinho 2003). Either higher or lower than normal PRL levels have been shown to compromise the immune responses in animal models (Elbourne et al. 1998). In vitro PRL has been shown to modulate the proliferation and effector function of $\mathrm{T}$ and $\mathrm{B}$ cells, macrophages and natural killer cells. Similarly, in vivo thymocytes and splenocytes synthesize and secrete PRL acting as autocrine or paracrine growth factor (Yu-Lee 1997).

PRL secretion is under dual regulation by hypothalamic hormones via the pituitary portal circulation. The predominant regulatory signal is the inhibition of PRL secretion by the neurotransmitter, dopamine, from neurons in the hypothalamus. The stimulatory signal for PRL secretion can be mediated by other factors including thyrotropin releasing hormone (TRH). Except for high levels of PRL observed during pregnancy and lactation, hyperprolactinemia is a pathological condition at any age. Any process (i.e. some medications) that disrupts dopamine secretion or interferes with the delivery of dopamine to the portal vessels may cause hyperprolactinemia (Table 1). Psychotropic agents causing hyperprolactinemia include the neuroleptics, tricyclic anti-depressants, monoamine oxidase inhibitors, serotonine reuptake inhibitors, opiates and cocaine, as well as several anti-hypertensive medications cause hyperprolactinemia, including $\alpha$-methyldopa, reserpine and verapamil. About $40 \%$ of all pituitary adenomas are prolactinomas. Micro- $(<1 \mathrm{~cm})$ or macroprolactinomas $(>1 \mathrm{~cm})$ contain lactotrops that secrete PRL. Age prevalence varies widely, and prolactinomas have been reported in patients from 2 to 80 years old. Prolactinomas are more common in women, with a peak incidence during the childbearing years.

The postpartum period is characterized hormonally by elevated levels of PRL and low levels of gonadotropins and sex steroids. During breast feeding, this state of postpartum amenorrhea can persist for an extended period, even though PRL levels decrease slowly. Although the action of PRL on multiple target sites has frequently been suggested as the cause of this ovarian quiescence, a 
Table 1 Causes of pathological hyperprolactinaemia.

\begin{tabular}{|c|c|c|}
\hline \multirow[t]{3}{*}{ Pituitary disorders } & $\begin{array}{l}\text { Pituitary tumours: micro- or macroprolactinoma, } \\
\text { hypothalamic stalk interruption }\end{array}$ & $\begin{array}{l}\text { Disruption of dopamine delivery from the } \\
\text { hypothalamus and/or secretion of prolactin by } \\
\text { the adenoma }\end{array}$ \\
\hline & Empty Sella syndrome & Damage to/regression of the pituitary \\
\hline & Infiltrative diseases (tuberculosis, sarcoidosis) & Infiltration of pituitary \\
\hline \multirow[t]{9}{*}{ Medications } & $\begin{array}{l}\text { Anti-psychotics (phenothiazines, haloperidol, } \\
\text { butyrophenones, risperidone, monoamine oxidase } \\
\text { inhibitors, fluoxetine, sulpiride) }\end{array}$ & Inhibition of dopamine release \\
\hline & Anti-emetics (metoclorpramide, domperidone) & \\
\hline & $\begin{array}{l}\text { Anti-hypertensives (methyldopa, calcium channel blockers, } \\
\text { reserpine) }\end{array}$ & \\
\hline & Tricyclic antidepressants & \\
\hline & Selective serotonin re-uptake inhibitors & \\
\hline & Opiates & Stimulation of hypothalamic opioid receptors \\
\hline & Estrogens & Positive action on lactotrophs \\
\hline & Verapamil & Unknown \\
\hline & Protease inhibitors & \\
\hline Primary hypothyroidism & & $\begin{array}{l}\text { Increased hypothalamic thyrotrophin-releasing } \\
\text { hormone and decreased metabolism }\end{array}$ \\
\hline Reduced prolactin elimination & $\begin{array}{l}\text { Renal failure } \\
\text { Hepatic insufficiency }\end{array}$ & \\
\hline
\end{tabular}

suckling-induced alteration in hypothalamic gonadotropin releasing hormone $(\mathrm{GnRH})$ production has also been suggested (Zinaman et al. 1995). Indeed, some authors demonstrated that hyperprolactinemia produces hypogonadism primarily by interfering with pulsatile GnRH release in males (Bouchard et al. 1985).

In young women, hyperprolactinemia is one of the most common endocrine disorders of the hypothalamicpituitary axis. It can be defined as the presence of an abnormally high level of PRL in the blood (normal levels are typically $10-28 \mu \mathrm{g} / \mathrm{L}$ in women and $5-10 \mu \mathrm{g} / \mathrm{L}$ in men). The prevalence of hyperprolactinemia varies in different patient populations, from $0.4 \%$ in an unselected normal population to up to $17 \%$ of women with reproductive disorders (Crosignani 1999). The increase in PRL levels observed in pathological hyperprolactinemia results in effects equivalent to those observed during the postpartum period, namely inhibition of the release of $\mathrm{GnRH}$ from the hypothalamus and subsequent inhibition of $\mathrm{LH}$ and follicle stimulating hormone (FSH), suppressed gonadal function. The consequence is that an elevated serum PRL from any cause results in anovulation with amenorrhea in women, but the degree of hypogonadism is frequently proportionate to the size of increase in PRL levels. In cases of marked hyperprolactinemia, amenorrhea and galactorrhea are frequently observed, while mild hyperprolactinemia may be associated with a short luteal phase and anovulatory infertility.

Multiple sampling has again revealed that $\mathrm{LH}(\mathrm{GnRH})$ pulse secretion is slow and of irregular amplitude. However, suppression of PRL by dopamine agonists rapidly restores pulsatile $\mathrm{LH}$ release, and ovulation usually ensues within few weeks. The irregular, slowfrequency $\mathrm{GnRH}$ pulses again appear to reflect increased hypothalamic opioid activity (Marshall et al. 2001).

Hyperprolactinemia in men may result in decreased libido, impotence, decreased sperm production, infertility (Colao et al. 2004). When hyperprolactinemia is caused by a prolactinoma, additional pressure symptoms may include headaches, visual field defects and abnormal pituitary function. The objectives of hyperprolactinemia therapy are to improve the symptoms associated with high PRL levels and to reduce the size of a pituitary tumor. Pharmacotherapy involves the use of dopamine agonists, which are able to decrease tumor size and reduce PRL secretion (Molitch 2003). The treatment of most patients is readily achieved using dopamine D2 receptor agonists, which can normalize serum PRL levels and shrink prolactinomas suitably to prevent any need of surgery.

\section{Conclusion}

The generation of a number of targeted mutagenesis models is increasingly being used to study reproductive function and also to understand fundamental processes of development. Until a few years ago, there was a strong discrepancy between the biological versatility of PRL and the paucity of clinical arguments to suggest a role for PRL in any human diseases. While awaiting the eventual identification of pathologies, resulting from genetic defects of PRL or PRLR, one immediate goal will be to understand how the amazing number of puzzling reports describing targets, mechanisms of actions or functions of PRL can be linked together and integrated into an overall physiological relevance of this pleitropic hormone.

\section{Acknowledgements}

Anne Bachelot held a fellowship from the Fondation pour la Recherche Médicale. The authors declare that there is no conflict of interest that would prejudice the impartiality of this scientific work. 


\section{References}

Ahonen TJ, Harkonen PL, Laine J, Rui H, Martikainen PM \& Nevalainen MT 1999 Prolactin is a survival factor for androgendeprived rat dorsal and lateral prostate epithelium in organ culture. Endocrinology 140 5412-5421.

Ali S, Chen Z, Lebrun JJ, Vogel W, Kharitonenkov A, Kelly PA \& Ullrich A 1996 PTP1D is a positive regulator of the prolactin signal leading to $\beta$-casein promoter activation. EMBO Journal 15 135-142.

Baldocchi RA, Tan L, King DS \& Nicoll CS 1993 Mass spectrometric analysis of the fragments produced by cleavage and reduction of rat prolactin: evidence that the cleaving enzyme is cathepsin D. Endocrinology 133 935-938.

Ben-Jonathan N, Mershon JL, Allen DL \& Steinmetz RW 1996 Extrapituitary prolactin: distribution, regulation, functions, and clinical aspects. Endocrine Review 17 639-669.

Berlanga JJ, Gualillo O, Buteau H, Applanat M, Kelly PA \& Edery M 1997 Prolactin activates tyrosyl phosphorylation of insulin receptor substrate-1 and phosphatidylinositol-3-OH kinase. Journal of Biological Chemistry 272 2050-2052.

Bernichtein S, Kinet S, Jeay S, Madern M, Martial JA, Kelly PA \& Goffin V 2001 S179D-hPRL, a pseudo-phosphorylated human prolactin analog, is an agonist and not an antagonist. Endocrinology 142 3950-3963.

Binart N, Helloco C, Ormandy CJ, Barra J, Clement-Lacroix P, Baran N \& Kelly PA 2000 Rescue of preimplantatory egg development and embryo implantation in prolactin receptor-deficient mice after progesterone administration. Endocrinology 141 2691-2697.

Binart N, Imbert-Bollore P, Baran N, Viglietta C \& Kelly PA 2003a A short form of the prolactin receptor is able to rescue mammopoiesis in heterozygous prolactin receptor mice. Molecular Endocrinology 17 1066-1074

Binart N, Melaine N, Pineau C, Kercret H, Touzalin AM, ImbertBollore P, Kelly PA \& Jegou B $2003 b$ Male reproductive function is not affected in prolactin receptor-deficient mice. Endocrinology 144 3779-3782.

Bole-Feysot C, Goffin V, Edery M, Binart N \& Kelly PA 1998 Prolactin and its receptor: actions, signal transduction pathways and phenotypes observed in prolactin receptor knockout mice. Endocrine Review 19 225-268.

Bouchard P, Lagoguey M, Brailly S \& Schaison G 1985 Gonadotropinreleasing hormone pulsatile administration restores luteinizing hormone pulsatility and normal testosterone levels in males with hyperprolactinemia. Journal of Clinical Endocrinology and Metabolism 60 258-262.

Bridges RS, Rigero BA, Byrnes EM, Yang L \& Walker AM 2001 Central infusions of the recombinant human prolactin receptor antagonist, S179D-PRL, delay the onset of maternal behavior in steroid- primed, nulliparous female rats. Endocrinology 142 730-739.

Brisken C, Kaur S, Chavarria TE, Binart N, Sutherland RL, Weinberg RA, Kelly PA \& Ormandy CJ 1999 Prolactin controls mammary gland development via direct and indirect mechanisms. Developmental Biology 210 96-106.

Brisken C, Ayyannan A, Nguyen C, Heineman A, Reinhardt F, Tan J, Dey SK, Dotto GP, Weinberg RA \& Jan T 2002 IGF-2 is a mediator of prolactin-induced morphogenesis in the breast. Developmental Cell 3 877-887.

Brown RJ, Adams JJ, Pelekanos RA, Wan Y, McKinstry WJ, Palethorpe K, Seeber RM, Monks TA, Eidne KA, Parker MW et al. 2005 Model for growth hormone receptor activation based on subunit rotation within a receptor dimer. Nature Structural and Molecular Biology 12 814-821.

Camarillo IG, Thordarson G, Moffat JG, Van Horn KM, Binart N, Kelly PA \& Talamantes F 2001 Prolactin receptor expression in the epithelia and stroma of the rat mammary gland. Journal of Endocrinology 171 85-95.
Clevenger CV, Ngo W, Sokol DL, Luger SM \& Gewirtz AM 1995 Vav is necessary for prolactin-stimulated proliferation and is translocated into the nucleus of a T-cell line. Journal of Biological Chemistry 270 13246-13253.

Colao A, Vitale G, Di Sarno A, Spiezia S, Guerra E, Ciccarelli A \& Lombardi G 2004 Prolactin and prostate hypertrophy: a pilot observational, prospective, case-control study in men with prolactinoma. Journal of Clinical Endocrinology and Metabolism 89 2770-2775.

Crosignani PG 1999 Management of hyperprolactinemia in infertility. Journal of Reproductive Medicine 44 1116-1120.

Davis JS, Rueda BR \& Spanel-Borowski K 2003 Microvascular endothelial cells of the corpus luteum. Reproductive Biology and Endocrinology 189.

Elbourne KB, Keisler D \& McMurray RW 1998 Differential effects of estrogen and prolactin on autoimmune disease in the NZB/NZW F1 mouse model of systemic lupus erythematosus. Lupus 7 420-427.

Feltus FA, Groner B \& Melner MH 1999 Stat5-mediated regulation of the human type II 3beta-hydroxysteroid dehydrogenase/delta5delta4 isomerase gene: activation by prolactin. Molecular Endocrinology 13 1084-1093.

Frasor J \& Gibori G 2003 Prolactin regulation of estrogen receptor expression. Trends in Endocrinology and Metabolism 14 118-123.

Freeman ME, Kanyicska B, Lerant A \& Nagy G 2000 Prolactin: structure, function, and regulation of secretion. Physiological Reviews 80 1523-1631.

Gadd SL \& Clevenger CV 2006 Ligand-independent dimerization of the human prolactin receptor isoforms: functional implications. Molecular Endocrinology 11 2734-2746.

Gallego MI, Binart N, Robinson GW, Okagaki R, Coschigano K, Perry J, Kopchick J, Oka T, Kelly PA \& Hennighausen L 2001 Prolactin, growth hormone and epidermal growth factor activate Stat5 in different compartments of mammary tissue and exert different and overlapping developmental effects. Developmental Biology 229 163-175.

Grosdemouge I, Bachelot A, Lucas A, Baran N, Kelly PA \& Binart N 2003 Effects of deletion of the prolactin receptor on ovarian gene expression. Reproductive Biology and Endocrinology 1 1-12.

Gu Y, Srivastava RK, Clarke DL, Linzer DI \& Gibori G 1996 The decidual prolactin receptor and its regulation by decidua-derived factors. Endocrinology 137 4878-4885.

Horseman ND \& Yu-Lee LY 1994 Transcriptional regulation by the helix bundle peptide hormones: growth hormone, prolactin, and hematopoietic cytokines. Endocrine Review 15 627-649.

Horseman ND, Zhao W, Montecino-Rodriguez E, Tanaka M, Nakashima K, Engle SJ, Smith F, Markoff E \& Dorshkind K 1997 Defective mammopoiesis, but normal hematopoiesis, in mice with a targeted disruption of the prolactin gene. EMBO Journal $\mathbf{1 6}$ 6926-6935.

Hovey RC, Trott JF, Ginsburg E, Goldhar A, Sasaki MM, Fountain SJ, Sundararajan K \& Vonderhaar BK 2001 Transcriptional and spatiotemporal regulation of prolactin receptor mRNA and cooperativity with progesterone receptor function during ductal branch growth in the mammary gland. Developmental Dynamics 222 192-205.

Hovey RC, Harris J, Hadsell DL, Lee AV, Ormandy CJ \& Vonderhaar BK 2003 Local insulin-like growth factor-II mediates prolactin-induced mammary gland development. Molecular Endocrinology 17 460-471.

Ihle JN 1996 STATs: signal transducers and activators of transcription. Cell 84 331-334.

Ihle JN \& Kerr IM 1995 Jaks and Stats in signaling by the cytokine receptor superfamily. Trends in Genetics 11 69-74.

Liu X, Robinson GW, Wagner KU, Garrett L, Wynshaw-Boris A \& Hennighausen L 1997 Stat5a is mandatory for adult mammary gland development and lactogenesis. Genes and Development 11 179-186. 
Lucas BK, Ormandy C, Binart N, Bridges RS \& Kelly PA 1998 Null mutation of prolactin receptor gene produces a defect in maternal behavior. Endocrinology 139 4102-4107.

Marshall JC, Eagleson CA \& McCartney CR 2001 Hypothalamic dysfunction. Molecular and Cellular Endocrinology 183 29-32.

Miyoshi K, Shillingford JM, Smith GH, Grimm SL, Wagner KU, Oka T, Rosen JM, Robinson GW \& Hennighausen L 2001 Signal transducer and activator of transcription (Stat) 5 controls the proliferation and differentiation of mammary alveolar epithelium. Journal of Cell Biology 155 531-542.

Molitch ME 2003 Pituitary tumors and pregnancy. Growth Hormone and IGF Research 13 S38-S44. Suppl A.

Nandi S 1958 Endocrine control of mammary gland development and function in the $\mathrm{C} 3 \mathrm{H} / \mathrm{He} \mathrm{Crgl}$ mouse. Journal of the National Cancer Institute 21 1039-1063.

Nevalainen MT, Valve EM, Ahonen T, Yagi A, Paranko J \& Harkonen PL 1997a Androgen-dependent expression of prolactin in rat prostate epithelium in vivo and in organ culture. FASEB Journal 11 1297-1307.

Nevalainen MT, Valve EM, Ingleton PM, Nurmi M, Martikainen PM \& Harkonen PL $1997 b$ Prolactin and prolactin receptors are expressed and functioning in human prostate. Journal of Clinical Investigation 99 618-627.

Neville MC \& Daniel CW 1987 The Mammary Gland: Development Regulation and Function, New York: Plenum Press.

Nilsson J, Bjursell G \& Kannius-Janson M 2006 Nuclear Jak2 and transcription factor NF1-C2: a novel mechanism of prolactin signaling in mammary epithelial cells. Molecular and Cellular Biology 26 5663-5674.

Niswender GD, Juengel JL, Silva PJ, Rollyson MK \& McIntush EW 2000 Mechanisms controlling the function and life span of the corpus luteum. Physiological Reviews 80 1-29.

Ormandy CJ, Camus A, Barra J, Damotte D, Lucas BK, Buteau H, Edery M, Brousse N, Babinet C, Binart N et al. 1997 Null mutation of the prolactin receptor gene produces multiple reproductive defects in the mouse. Genes and Development 11 167-178.

Ormandy CJ, Naylor M, Harris J, Robertson F, Horseman ND, Lindeman GJ, Visvader J \& Kelly PA 2003 Investigation of the transcriptional changes underlying functional defects in the mammary glands of prolactin receptor knockout mice. Recent Progress in Hormone Research 58 297-323.

Piwnica D, Fernandez I, Binart N, Touraine P, Kelly PA \& Goffin V 2006 A new mechanism for prolactin (PRL) processing into 16K PRL by secreted cathepsin D. Molecular Endocrinology 20 3263-3278.

Prigent-Tessier A, Tessier C, Hirosawa-Takamori M, Boyer C, FergusonGottschall S \& Gibori G 1999 Rat decidual prolactin. Identification, molecular cloning, and characterization. Journal of Biological Chemistry 274 37982-37989.

Qazi AM, Tsai-Morris CH \& Dufau ML 2006 Ligand-independent homo- and hetero-dimerization of human prolactin receptor variants: inhibitory action of the short forms by heterodimerization. Molecular Endocrinology 8 1912-1923.

Reynolds LP \& Redmer DA 1999 Growth and development of the corpus luteum. Journal of Reproduction and Fertility Supplement 54 181-191.

Risk M \& Gibori G 2001 Mechanisms of luteal cell regulation by prolactin. In Prolactin, pp 265-295. Ed. ND Horseman. Boston: Kluwer Academic Publishers.
Robertson FG, Harris J, Naylor MJ, Oakes SR, Kindblom J, Dillner K, Wennbo H, Tornell J, Kelly PA, Green J et al. 2003 Prostate development and carcinogenesis in prolactin receptor knockout mice. Endocrinology 144 3196-3205.

Saunier E, Dif F, Kelly PA \& Edery M 2003 Targeted expression of the dominant-negative prolactin receptor in the mammary gland of transgenic mice results in impaired lactation. Endocrinology 144 2669-2675.

Shingo T, Gregg C, Enwere E, Fujikawa H, Hassam R, Geary C, Cross JC \& Weiss S 2003 Pregnancy-stimulated neurogenesis in the adult female forebrain mediated by prolactin. Science 299 117-120.

Sinha YN 1995 Structural variants of prolactin: occurence and physiological significance. Endocrine Review 16 354-369.

Sobrinho LG 2003 Prolactin, psychological stress and environment in humans: adaptation and maladaptation. Pituitary 6 35-39.

Steger RW, Chandrashekar V, Zhao W, Bartke A \& Horseman ND 1998 Neuroendocrine and reproductive functions in male mice with targeted disruption of the prolactin gene. Endocrinology 139 3691-3695.

Tamanini C \& De Ambrogi M 2004 Angiogenesis in developing follicle and corpus luteum. Reproduction in Domestic Animals 39 206-216.

Tan D, Johnson DA, Wu W, Zeng L, Chen YH, Chen WY, Vonderhaar BK \& Walker AM 2005 Unmodified prolactin (PRL) and S179D PRLinitiated bioluminescence resonance energy transfer between homoand hetero-pairs of long and short human PRL receptors in living human cells. Molecular Endocrinology 19 1291-1303.

Udy GB, Towers RP, Snell RG, Wilkins RJ, Park SH, Ram PA, Waxman DJ \& Davey HW 1997 Requirement of Stat5b for sexual dimorphism of body growth rates and liver gene expression. PNAS 94 7239-7244.

Wakao H, Gouilleux F \& Groner B 1995 Mammary gland factor (MGF) is a novel member of the cytokine regulated transcription factor gene family and confers the prolactin response. EMBO Journal 14 854-855.

Walker SE, Miller D, Hill DL \& Komatireddy GR 1998 Prolactin, a pituitary hormone that modifies immune responses. Proceedings of the Mini-symposium on Prolactin and SLE, held at the 5th International Conference on Systemic Lupus Erythematosus, Cancun, Mexico. Lupus 7 371-375.

Webb R, Woad KJ \& Armstrong DG 2002 Corpus luteum (CL) function: local control mechanisms. Domestic Animal Endocrinology 23 277-285.

Wu W, Coss D, Lorenson MY, Kuo CB, Xu X \& Walker AM 2003 Different biological effects of unmodified prolactin and a molecular mimic of phosphorylated prolactin involve different signaling pathways. Biochemistry 42 7561-7570.

Yu-Lee LY 1997 Molecular actions of actions of prolactin in the immune system. Proceedings of the Society for Experimental Biology Medicine 215 35-51.

Zinaman MJ, Cartledge T, Tomai T, Tippett P \& Merriam GR 1995 Pulsatile GnRH stimulates normal cyclic ovarian function in amenorrheic lactating postpartum women. Journal of Clinical Endocrinology and Metabolism 80 2088-2093.

Received 27 October 2006

First decision 21 November 2006

Accepted 11 December 2006 